DOI 10.37882/2223-2982.2021.07.43

\title{
ПРОЦЕСС ФИЗИЧЕСКОГО ВОСПИТАНИЯ В ОБРАЗОВАТЕЛЬНЫХ УЧРЕЖДЕНИЯХ СТРАН ЕВРОПЫ И АЗИИ: СРАВНИТЕЛЬНЫЙ АСПЕКТ
}

\section{THE PROCESS OF PHYSICAL EDUCATION IN EDUCATIONAL INSTITUTIONS \\ OF THE COUNTRIES OF EUROPE AND ASIA: COMPARATIVE ASPECT}

Jia Ran

Summary: The article actualizes the problems of the organization and content of the process of physical education in different countries. The author approaches the issue by analyzing the systems of physical education in Europe and Asia. The article reveals the specificity of the process of physical education, as well as cultural, ideological, pedagogical features. The experience of physical education in the countries of Europe and Asia differs in its diversity in the content part, as well as in the part of modeling according to educational tasks that are solved in the process of teaching physical culture. The difference in the theoretical and methodological foundations of the organization of the process of physical education is due to cultural national traditions characteristic of education systems.

Keywords: physical education, countries of Europe and Asia, features, organization, content.

\author{
цзя Жань \\ Цзилиньский педагогический университет, Китай \\ 35600802@q9.com
}

Аннотация: В статье актуализируется проблематика организации и содержания процесса физического воспитания в разных странах. Автор подходит к решению вопроса путем анализа систем физического воспитания в странах Европы и Азии. В статье выявлена специфика процесса физического воспитания, а также культурные, идеологические, педагогические особенности. Опыт физического воспитания в странах Европы и Азии различается своим разнообразием в содержательной части, а также в части моделирования согласно образовательным задачам, которые решаются в процессе преподавания физической культуры. Различие теоретико-методологических основ организации процесса физического воспитания обусловлено культурными национальными традициями, характерными для систем образования.

Ключевые слова: физическое воспитание, страны Европы и Азии, особенности, организация, содержание. роблематика физического воспитания подрастающего поколения и молодежи является на сегодняшний день одной из важнейших и насущных в системе образования в мировом масштабе. Нет ни одной страны, которая не уделяла бы серьезное внимание организации этого процесса в образовательных учреждениях. В связи с этим, дисциплины, в основе которых лежит педагогический процесс физического воспитания, а также внеурочные виды физической спортивной и физкультурно-оздоровительной деятельности рассматриваются в числе приоритетных в большинстве развитых стран [8].

В последнее время внимание ученых соответствующей области привлекает аналитический подход к выявлению специфики процесса физического воспитания в различных странах, а также в странах Европы и Азии. Это связано не только с вопросами поиска путей осуществления эффективного здоровьесбережения представителей различных наций, народов, но и выявления специфики культурных особенностей (а, как известно, физическая культура представляет собой часть общей культуры общества), потенциала культурных националь- ных традиций в процессе физического воспитания личности и др. $[4 ; 5]$.

Так, вопросам исследования особенностей физического воспитания в разных странах уделяли внимание такие ученые как Д.С. Молоков, А.Д. Викулов, Л.Н. Данилова, Е.А. Уваров, Белаид Моджахед, В.Н. Кремнева и др. (Молоков, Викулов, Данилова, 2019; Уваров, Моджахед, 2017; Кремнева, Солодовник, 2019) [2; 4; 8].

Особенностям формирования физической культуры личности в странах Европы посвящали свои исследования И.В. Норицына, Н.В. Ямбаева, А.К. Намазов, И.С. Газиева и др. (Норицына, Ямбаева, 2018; Намазов, Газиева, 2016) $[5 ; 6]$.

Различиям в системах физического воспитания уделяли внимание Д. Д. Любимова, О.А. Веденина, В.Д. Иванов, Н.А. Салькова, Й. Хуа, С.Н. Талызов и др. (Любимова, Веденина, 2020; Иванов, Салькова, 2017; Хуа, 2004; Талы3ов, 2016) $[1 ; 3$; 7].

Говоря о специфике организации и содержания про- 
цесса физического воспитания в странах Европы и Азии, необходимо отметить, что в образовательных учреждениях многих европейских стран физическое воспитание, помимо обязательных программ, широко присутствует в программах факультативов. В то же время, содержательно оно не повторяет обязательные программы по физической культуре. Так, например, если в обязательной программе физического воспитания присутствует плавание, то, в факультативных занятиях оно представлено такими видами как водное поло, синхронное плавание и пр.

Помимо такого тематического разнообразия, содержание процесса физического воспитания построено и с учетом гендерного подхода: так, в основном, мальчикам/юношам предлагаются занятия игровыми видами на воде (например, водное поло), а девочкам/девушкам - освоение элементов синхронного плавания. Такая практика осуществляется в Австрии, Германии, Польше, Чехии, Швеции и т.д. [4].

Необходимо отметить, что традиционно сложившаяся система классно-урочной формы обучения в европейских странах и системный подход к формированию физической культуры личности определил важнейшие принципы к организации физического воспитания преемственность и непрерывность. Это проявляется в том, что, если обязательный программный материал осваивается обучающимися не в полной мере, то освоение программы продолжается в летний период, предусматривающий курс дополнительных занятий. Таким образом, в задачи каждого обучающегося входит формирование собственной траектории физического развития и оздоровления. Для эффективного решения этих задач привлекается потенциал основного и дополнительного образования [4;6].

Физическая культура и спортивно-оздоровительная деятельность занимают важное место не только в системе образования, но в семейном воспитании, задачи которого (в отношении физического развития обучающихся) синхронизируются с задачами образовательных учреждений. Так, например, в системе образования Франции практикуется родительское руководство спортивными секциями и проведением занятий по физической культуре.

Огромное значение придается режимным моментам в распорядке учебного дня: например, учебные занятия всегда чередуются с физкультурно-оздоровительной деятельностью на воздухе (этот могут быть подвижные игры, самостоятельные занятий на спортивных площадках и др.). Такая деятельность осуществляется помимо академической нагрузки по физической культуре в образовательном процессе. Физкультурно-оздоровительная деятельность представлена в режиме дня такими видами как оздоровительная гимнастика и акробатика, аэробика и ритмика, всевозможные игры и т.д. Помимо этого, практические занятия дополняются теоретическими. Теоретический аспект дополняет практику физического воспитания в плане сопутствующих вопросов здоровьесбережения обучающихся (вопросы правильного питания, гигиена труда и отдыха, закаливающие процедуры и пр.

Европейское образование также ориентировано не только на укрепление здоровья - важнейшей стратегией выступает формирование конкурентоспособной личности, ее успешной социализации в обществе [4].

Резюмируя особенности физического воспитания в системе европейского образования можем отметить, направленность физического воспитания на формирование индивидуальной траектории личностного физического развития. Для достижения этой цели используется разнообразный спектр средств физической культуры и спорта, которые зачастую не являются распространенными в рамках учебных дисциплин в ряде других стран (например, горнолыжные школы, гольф, парусный спорт, синхронное плавание, крикет, гольф и др.).

В отличие от стран Европы, страны Азии имеют в основе организации и содержания физического воспитания исторически сформированные традиции коллективной ответственности. Идеолого-мировоззренческие императивы коллективизма как фактора сплоченности и успешного будущего своей нации представлены, например, в системе японского физического воспитания таким принципом как «все делают, и я буду» - так в процессе физического воспитания формируется социальный национальный пример.

В системе образования (в том числе в физической культуре) Китая реализуется принцип «трёх «хорошо», а именно «быть хорошо физически и функционально подготовленным» для того, чтобы в дальнейшем содействовать прогрессивному развитию своего государства. Этот принцип регулирует подходы физического воспитания, в котором широко используются методы спортивной тренировки, подразумевающий высокий уровень дисциплинированности обучающихся $[1 ; 2 ; 4]$.

В странах Азии, как правило, осуществляется глубоко профессиональный подход к процессу физического воспитания: каждый конкретный вид физкультурно-оздоровительной и спортивной деятельности преподается профессионалом-педагогом в данном конкретном виде спорта, в связи с чем, в процессе учебы в образовательном учреждении (например, в Японии) обучающиеся могут становиться профессионалами в том или ином виде спорта.

Помимо этого, следует акцентировать внимание на 
том, что в процессе физического воспитания индивидуальный особенности каждого конкретного обучающегося не культивируются. Обучающиеся совершенствуются, в основном, в коллективной деятельности: коллективные мероприятия, соревнования, походы и т.д., что подразумевает достижение высокого общего уровня физического развития данного коллектива.

Следует отметить, что азиатские страны не располагают всем масштабом условий, которые используются европейские страны. В связи с этим, в странах Азии к процессу физического воспитания привлекаются все имеющиеся возможности, например, реализуется много игровых видов на воздухе, верховая езда, стрельбы и т.п.
Основной стратегией физического воспитания в странах Азии, в основном, является направленность на укрепление здоровье, духовное развитие, подкрепленное физическим совершенствованием.

Подводя итоги статьи, считаем необходимым еще раз отметить, что опыт физического воспитания в странах Европы и Азии различается своим разнообразием в содержательной части, а также в части моделирования согласно образовательным задачам, которые решаются в процессе преподавания физической культуры. Различие теоретико-методологических основ организации процесса физического воспитания обусловлено культурными национальными традициями, характерными для систем образования.

\section{ЛИТЕРАТУРА}

1. Иванов В.Д., Салькова Н.А. Особенности физической культуры и спорта в странах Азии // Физическая культура. Спорт. Туризм. Двигательная рекреация. - 2017. - № 1. - С. 32-34.

2. Кремнева В.Н., Солодовник Е.М. Сравнение систем образования в области физической культуры в школах России и Японии // Международный журнал гуманитарных и естественных наук. - 2019. - № 8-1. - С. 92-96. doi:10.24411/2500-1000-2019-11464

3. Любимова Д.Д., Веденина 0.А. Различия в системах физического воспитания в высших учебных заведениях США и России // Физическая культура, спорт и здоровье студенческой молодежи в современных условиях: проблемы и перспективы развития: Материалы Региональной студенческой научно-практической конференции. - Екатеринбург, 2020. - С. 132-136.

4. Молоков Д.С., Викулов А.Д., Данилова Л.Н. Физическое воспитание школьников в зарубежных системах общего и дополнительного образования // Вестник Томского государственного университета. - 2019. - № 443. - С. 236-240.

5. Намазов А.К., Газиева И.С. Массовый спорт за рубежом // Здоровье - основа человеческого потенциала: проблемы и пути их решения. - 2016. - № 1. C. 433-437.

6. Норицына И.В., Ямбаева Н.В. Физическая культура и спорт в странах Европы // Инновации в науке и практике: (борник статей по материалам VII международной научно-практической конференции. В 5-ти частях. - Уфа, 2018. - С. 16-23.

7. Талызов С.Н. Корейская модель управления культурой и спортом // Физ. культура. Спорт. Туризм. Двигат. рекреация. - 2016. - Т. 1, № 4. - С. 101-103.

8. Уваров Е.А., Белаид Моджахед, Яхяви Саид. Содержание программ физического воспитания в школах Европы и России // Вестник Тамбовского университета. Серия: Гуманитарные науки. - 2017. - № 5 (169). - С. 120-125.

(c) Цзя Жань (35600802@qq.com).

Журнал «Современная наука: актуальные проблемы теории и практики» 